\title{
Non-transmissibility of the $Y$ chromosome through the female line in androhermaphrodite plants of Melandrium album
}

\author{
BOHUSLAV J ANOUŠEK, SARAH R. GRANT† \& BORIS VYSKOT* \\ Institute of Biophysics, Czech Academy of Sciences, Královopolská 135, 61265 Brno, Czech Republic, and \\ †Department of Biology and Curriculum in Genetics and Molecular Biology, University of North Carolina, Chapel \\ Hill, NC 27599-3280, U.S.A.
}

\begin{abstract}
Androhermaphrodite plants of dioecious Melandrium album (syn. Silene latifolia), forming both bisexual and male flowers, were isolated from seeds treated with a hypomethylating drug, 5 -azacytidine. These plants possessed the standard male karyotype $(2 n=24, \mathrm{XY})$, and the androhermaphrodite trait was inherited when these plants were self-pollinated or used as pollen donors. To determine whether or not their Y chromosome can be transmitted through the female line, an androhermaphrodite was crossed with an X-ray-induced hermaphrodite harbouring a large deletion on the $\mathrm{Y}$ chromosome, which makes it unable to pass through male or female meiosis. When this mutant hermaphrodite was pollinated with the androhermaphrodite, the seed progeny consisted of male, androhermaphrodite and female plants, whereas the reciprocal cross yielded female plants only. The genotypes of both parents and progeny were verified by karyological and restriction fragment length polymorphism (RFLP) analyses. The results show that the $\mathrm{Y}$ chromosome cannot pass through the female line, probably because of the absence of an $\mathrm{X}$ chromosome during embryo sac formation or an imbalance of $\mathrm{X} / \mathrm{Y}$ chromosomes in developing endosperm.
\end{abstract}

Keyw ords: dioecious plants, epimutation, hermaphrodites, Melandrium album, Silene latifolia, Y chromosome.

\section{Introduction}

Melandrium album Garcke (syn. Silene latifolia Poiret, Caryophyllaceae) is a model dioecious plant species with an $\mathrm{X} / \mathrm{Y}$ chromosome-based sex determination system. The $\mathrm{Y}$ chromosome plays a crucial role in sex determination, as it carries femalesuppressing genes and male-determining genes necessary for both early and mature anther development (Westergaard, 1958; Grant et al., 1994). In this species, segregation of the $\mathrm{X}$ and $\mathrm{Y}$ chromosomes occurs in male meiosis; females are the homogametic gender (the AAXX constitution). Some plants of AAXY constitution are hermaphrodite (all flowers are bisexual) or androhermaphrodite (forming both bisexual and male flowers on the same individual). The occurrence of bisexual flowers can be caused by a mutation (deletion) of the female-suppressing genes on the $\mathrm{Y}$ chromosome or as a consequence of a spontaneously or artificially induced change in the DNA methylation pattern (Janoušek et al., 1996). Androhermaphrodites

*Correspondence. E-mail: vyskot@ibp.cz possessing the standard male karyotype were obtained using a hypomethylating drug, 5-azacytidine. Genetic analysis of the transmission of this trait revealed uniparental inheritance: the androhermaphroditism was inherited if the androhermaphrodites were used as pollen donors but was not transmitted if the androhermaphrodites were pollinated by wild-type males. This result could be explained by two alternative hypotheses. The first supposes that androhermaphroditism is a trait caused by an autosomally linked epimutation, with incomplete penetrance and varying expressivity. In this case, its inheritance must be influenced by an epigenetic mechanism erasing the epimutation during female meiosis (parental imprinting). The second hypothesis has two premises: the epimutation causing the androhermaphroditism is $\mathrm{Y}$ chromosome-linked and the $\mathrm{Y}$ chromosome cannot be transmitted through the female line (Janoušek et al. 1996).

The penetration of the $\mathrm{Y}$ chromosome through the female line presumes the formation of megaspores of the AY chromosome constitution (no X 
chromosome). The question is whether such megaspores are viable and able to give rise to an embryo sac and later embryo and endosperm. In evolutionarily less advanced dioecious plant species, such as Asparagus (Westergaard, 1958) and kiwifruit (Testolin et al., 1995), it is possible to obtain, after selfpollination of AAXY hermaphrodites, progeny plants possessing the chromosome constitution AAYY, suggesting that one of the above-mentioned premises was fulfilled. Self-pollination of Melandrium rubrum androhermaphrodite plants (androhermaphrodites occur very rarely in natural populations) yielded no plants of the AAYY chromosome constitution (Van Nigtevecht, 1966a). The fact that there was no significant difference in the gender ratio between the progenies obtained after self-pollination of $M$. rubrum androhermaphrodites (the expected ratio is one female to two males or androhermaphrodites, if the AAYY combination is lethal) and wild-type female $\times$ androhermaphrodite crosses (the expected ratio is one female to one male) suggests that the $\mathrm{Y}$ chromosome is probably not transmitted through the female line (Van Nigtevecht, 1966a). There is, however, no direct evidence for this, because a reduction in the number of effective $\mathrm{Y}$ chromosome-carrying gametes could (as a result of competition) occur in both lines simultaneously, giving an impression of $\mathrm{Y}$ chromosome absence in female gametes.

Sex ratio shows great variation in populations of M. album. It was postulated by Correns (1928) that pollen tubes developed from the $\mathrm{X}$ chromosome pollen grains reach the ovary earlier than those possessing the $\mathrm{Y}$ chromosome. It was also speculated that there is a corresponding size difference between the two pollen grain types. However, experiments using size-selected pollen affected neither fruit and seed setting nor progeny gender (Caroll \& Mulcahy, 1991). It is, therefore, clear that the bias must be realized later, during male gametophyte growth (pollen tubes), seed setting or early plant development. Recent studies have shown that the sex ratio polymorphism is inherited through or expressed in the male parent. The sex ratio from reciprocal crosses was significantly different, indicating either sex-linkage or cytoplasmic inheritance of the sex ratio (Taylor 1994). Taylor concludes that sex ratio is controlled by several loci, one of them being a Y-linked sex ratio modifier, which is expressed prezygotically (in the male gametophyte), because no post-zygotic mortality could be detected (Taylor 1993).

In this study, we have followed $\mathrm{Y}$ chromosome transmission through the female gametophyte in $M$. album in reciprocal crosses between an androhermaphrodite and an X-ray-induced hermaphrodite. This hermaphrodite is unable to pass its Y chromosome through either pollen or eggs, as it carries a large deletion in the $\mathrm{Y}$ chromosome. Because of this, any male or bisexual plants in these progenies must have received a $\mathrm{Y}$ chromosome from the AAXY androhermaphrodite parent.

\section{Materials and methods}

\section{Plant materials}

The following plants of M. album were used (either from natural populations or experimentally modified).

The androhermaphrodite plant $(\mathrm{AH})$ was selected from the progeny of the (A1) androhermaphrodite plant induced by 5-azacytidine (Janoušek et al., 1996) in the Olomouc ecotype (kindly provided by J. Vagera, Institute of Experimental Botany, Olomouc, Czech Republic). The AH plant was selected from the cross of siblings, S4 and S1, which had been obtained after self-pollination of the original A1 androhermaphrodite. This particular $\mathrm{AH}$ plant was chosen because it formed many bisexual flowers and could be used repeatedly as both a seed parent and a pollen donor. Wild-type male (WM) and female (WF) plants were from the same source (the Olomouc ecotype). This material is strictly dioecious and, although it has been cultured and crossed in large glasshouse populations for 5 years, no spontaneous sex deviation has ever been observed.

The hermaphrodite plant (H8), forming bisexual flowers only, was induced using X-ray mutagenesis of pollen grains (Donnison et al., 1996). In this case, an inbred M. album line (propagated by sister $\times$ brother matings for six generations), kindly provided by J. van Brederode (University of Utrecht, The Netherlands), was used as starting plant material.

\section{Genetic analysis}

In order to follow the transmissibility of the $\mathrm{Y}$ chromosome through the female meiosis, a pollen donor that never transmits its $\mathrm{Y}$ chromosome (hermaphrodite clone H8) was used. All the other possible crosses of parental plants (including wildtype male and female) were made, forming the $3 \times 3$ diallele.

Where flowers from the androhermaphrodite (AH) or hermaphrodite (H8) plants were used as seed parents, they were emasculated before anther maturation and dehiscence. The plants were then cultured in isolated boxes to prevent open pollina- 
tion and finally pollinated with selected pollen donors. Seeds obtained from the crosses were sterilized and germinated on MS agar medium. Seedlings were transferred into pots, cultured in glasshouse conditions and, upon flowering, the sex of at least 300 flowers on each plant was checked.

\section{Karyotype analysis}

To evaluate plant karyotypes, with an emphasis on the presence and morphology of sex chromosomes, germinating seeds (or in the case of $\mathrm{H} 8$, roots emerging in plant axenic cultures) were synchronized with aphidicoline $(30 \mu \mathrm{M}$, for $12 \mathrm{~h})$, and metaphase arrest was performed $10 \mathrm{~h}$ later with oryzalin $(10 \mu \mathrm{M}$, for $2 \mathrm{~h})$. Root tips were enzymatically transformed into protoplasts, fixed in Carnoy fixative and chromosomes stained with 5\% Giemsa solution (according to Vyskot et al., 1993).

\section{Pollen viability}

Pollen viability was evaluated using the standard aceto-carmine method and expressed as the proportion of pollen grains that stained red.

\section{Plant DNA isolation and Southern hybridization}

Total genomic DNA was isolated from fresh leaves according to a standard protocol (Dellaporta et al., 1983) and purified by phenol and chloroform extraction. DNAs were cut with an excess of BglII restriction enzyme $\left(10 \mathrm{U}_{\mu \mathrm{g}}{ }^{-1}\right)$. Cleaved DNA samples ( $5 \mu \mathrm{g}$ per each line) were separated on $1 \%$ agarose gels, transferred to Hybond-N (Amersham) membrane and hybridized to an anonymous DNA probe no. 35. This DNA fragment, $700 \mathrm{bp}$ long, was prepared from total genomic $M$. album DNA using RDA protocol and cloned into the BamHI site of BluescriptKS + (Stratagene) (Donnison et al., 1996). The recombinant plasmid DNA was labelled with $\left[\alpha-{ }^{32} \mathrm{P}\right]$-dCTP using the Decaprime kit. The membranes were washed under stringent conditions $\left(0.2 \times \mathrm{SSC}, \quad 0.1 \%\right.$ SDS, $\left.60^{\circ} \mathrm{C}\right)$, and hybridization signals were visualized on a Phosphorimager using IMAGEQUANT software.

The completeness of DNA digestion with BglII was checked by rehybridization of the blots with a digoxigenin-labelled chloroplast DNA clone as described previously (Bužek et al., 1997).

\section{Results}

\section{Characterization of parental plant material}

Flowers of the wild-type male (WM) possessed 10 well-developed stamens with anthers of standard size
(Fig. 1a). Flowers of the wild-type female (WF) contained a fully developed gynoecium composed of five carpels (Fig. 1b). The androhermaphrodite plant (AH) possessed, apart from normal male flowers, a high proportion (about one-third) of bisexual flowers. Each of these bisexual flowers had 10 stamens and one gynoecium consisting of one to five carpels. There was great variation in the gynoecium, but some of them were well developed and possessed fertile ovules (Fig. 1c). All the flowers of the hermaphrodite plant $\mathrm{H} 8$ were bisexual with a morphologically well-developed gynoecium. However, the gynoecium fertility was rather low: this plant produced only small numbers of badly germinating seeds (compared with the WF and $\mathrm{AH}$ plants, Table 1). The stamens were short and carried small anthers in comparison with the wild-type male or androhermaphrodite plants. Table 1 also shows the results of pollen analysis, which revealed a significantly decreased pollen fertility of the hermaphrodite $\mathrm{H} 8$ when compared with the wild-type male $(\mathrm{WM})$ and androhermaphrodite $(\mathrm{AH})$ plants.

\section{Karyological analysis of parental plants and their progeny}

The karyological analysis of the $\mathrm{H} 8$ hermaphrodite plant revealed a large deletion on one arm of the $\mathrm{Y}$ chromosome (Fig. 2a). As this deletion correlates with the loss of female-suppressing function, it is obviously localized on the non-homologous arm of the Y chromosome (Westergaard, 1958). The imperfect stamen development and low pollen fertility of this hermaphrodite plant also indicate that some stamen development gene(s) located on the Y chromosome have also been affected by the deletion (Donnison et al., 1996). The androhermaphrodite AH displayed the standard male karyotype $(2 n=24$, $\mathrm{XY}$ ) with the metacentric Y chromosome (Fig. 2b). This result confirmed our previous analysis made on the original, 5-azacytidine-treated androhermaphrodite (Janoušek et al., 1996). Cytological analysis of plants from the $\mathrm{AH} \times \mathrm{H} 8$ cross showed that all had the standard female karyotype $(2 n=24, \mathrm{XX}$; Fig. 2c).

\section{Genetic analysis}

The results of genetic analyses are presented in Table 2 and can be summarized as follows. Neither androhermaphrodites nor hermaphrodites occurred in the control cross between the wild-type female and male $(\mathrm{WF} \times \mathrm{WM})$ plants (Table 2a). This confirmed the strict dioecy of the original Olomouc ecotype. Only female plants were found in the self-

(C) The Genetical Society of Great Britain, Heredity, 80, 576-583. 
progeny of hermaphrodite plant $\mathrm{H} 8(\mathrm{H} 8 \times \mathrm{H} 8)$ as well as in the cross in which the wild-type female was pollinated with the hermaphrodite $\mathrm{H} 8$ $(\mathrm{WF} \times \mathrm{H} 8)$. The absence of both males and hermaphrodites proved that the aberrant Y chromosome cannot pass through either female or male lines (Donnison et al., 1996). However, some male plants were present when the plant $\mathrm{H} 8$ was pollinated with the wild-type male $(\mathrm{H} 8 \times \mathrm{WM})$, their $\mathrm{Y}$ chromosome being derived from the wild-type pollen donor (Table 2b). Females and males (but no androhermaphrodites) were produced when the androhermaphrodite was pollinated with the wild- type male $(\mathrm{AH} \times \mathrm{WM})$. However, a majority of the AAXY plants were androhermaphrodite if the androhermaphrodite had been self-pollinated $(\mathrm{AH} \times \mathrm{AH})$ or used as the pollen donor to the wildtype female $(\mathrm{WF} \times \mathrm{AH}$, Table $2 \mathrm{c})$. There was no significant difference in the frequency of androhermaphrodites among the AAXY plants between the populations $\mathrm{AH} \times \mathrm{AH}$ and $\mathrm{WF} \times \mathrm{AH}$, when tested using a $2 \times 2$ contingency table $\left(\chi_{1}^{2}=2.71, P=0.10\right)$. Although the cross between the hermaphrodite as seed parent and the androhermaphrodite as pollen donor $(\mathrm{H} 8 \times \mathrm{AH})$ yielded, apart from females, both males and androhermaphrodites, the progeny of the
Fig. 1 Flower morphology of parental Melandrium album (petals and sepals removed). (a) Wild-type male, WM; (b) wild-type female, WF; (c) androhermaphrodite, AH (bisexual flower, front wall of the ovary removed); (d) hermaphrodite, H8.
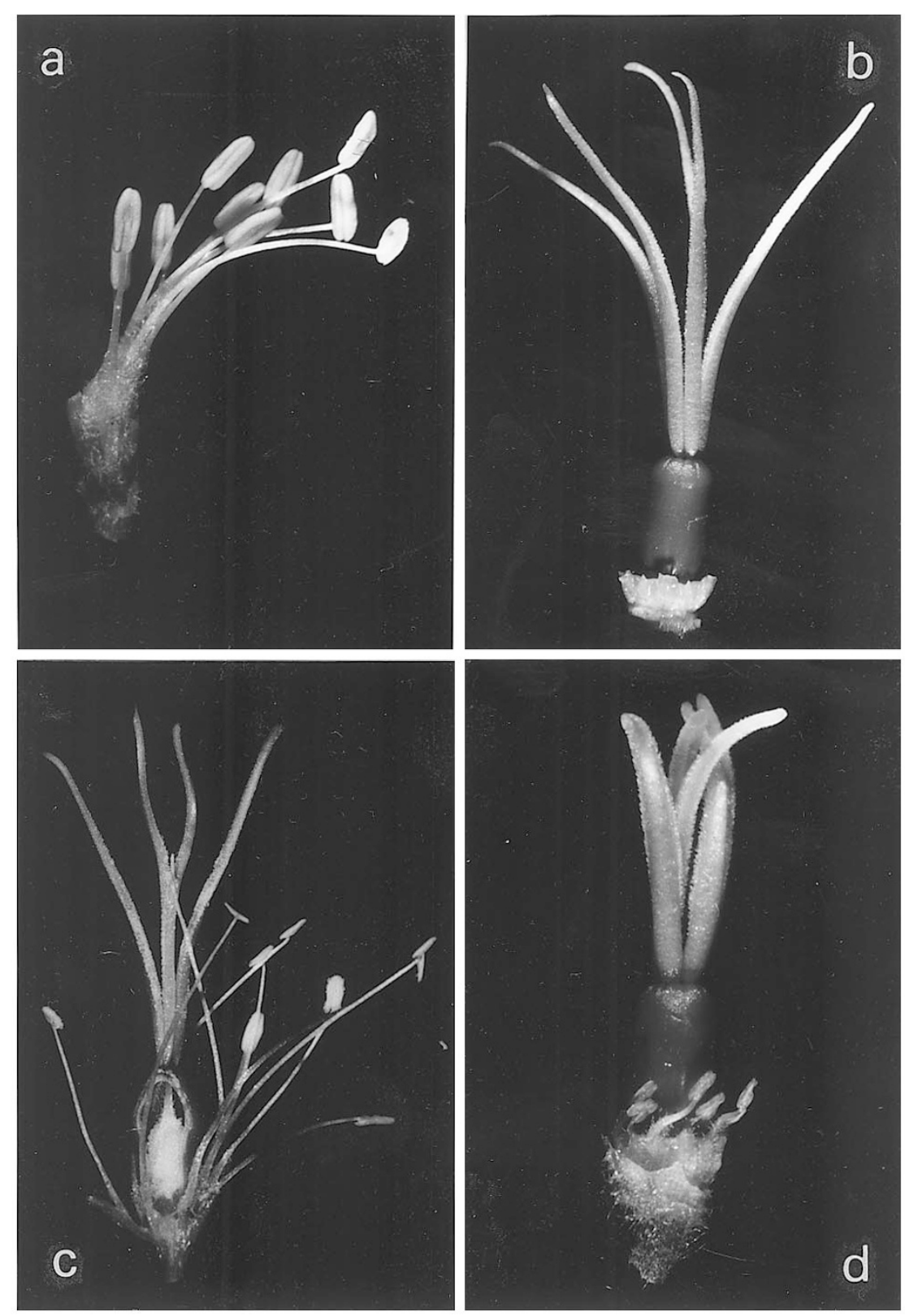
reciprocal cross $(\mathrm{AH} \times \mathrm{H} 8)$ consisted of female plants only (Table 2d; Fig. 2c). Slightly higher numbers of females were observed in all the progenies in which the plants $\mathrm{AH}$ or WM served as pollen donors. In two cases $(\mathrm{WF} \times \mathrm{WM}$ and $\mathrm{AH} \times \mathrm{WM}$ ), a significant deviation from the expected sex ratio of one female to one androhermaphrodite or male was found (Table 2). No difference was detected between WM and $\mathrm{AH}$ when testing the female bias in cumulated progenies using the $2 \times 2$ contingency table $\left(\chi_{1}^{2}=1.4, P=0.23\right)$.

Table 1 Pollen fertility and seed germination in hermaphrodite (H8), androhermaphrodite (AH) and wildtype Melandrium album (WM and WF)

\begin{tabular}{lccccc}
\hline & \multicolumn{2}{c}{ Pollen fertility } & & \multicolumn{2}{c}{$\begin{array}{c}\text { Seed } \\
\text { Germination }\end{array}$} \\
\cline { 2 - 3 } Genotype & $(\%)$ & $(\mathrm{SE})$ & & $(\%)$ & $(\mathrm{SE})$ \\
\hline H8 & $28.2^{*}$ & $(2.6)$ & & $43.4 \dagger$ & $(4.3)$ \\
AH & 91.9 & $(1.6)$ & 69.4 & $(3.6)$ \\
WM & 92.6 & $(1.2)$ & & - & \\
WF & - & & & 75.6 & $(1.9)$ \\
\hline
\end{tabular}

As the influence of pollen donor on the seed germination was negligible (when tested using contingency tables; data not shown), all the samples of identical seed parents were pooled: $(\mathrm{H} 8 \times \mathrm{WM}, \mathrm{H} 8 \times \mathrm{AH}$ and $\mathrm{H} 8 \times \mathrm{H} 8)$ for $\mathrm{H} 8$,

$(\mathrm{AH} \times \mathrm{WM}, \mathrm{AH} \times \mathrm{AH}$ and $\mathrm{AH} \times \mathrm{H} 8)$ for $\mathrm{AH}$ and

$(\mathrm{WF} \times \mathrm{WM}, \mathrm{WF} \times \mathrm{AH}$ and $\mathrm{WF} \times \mathrm{H} 8)$ for $\mathrm{WF}$.

*Significantly different from WM, when tested using the

$2 \times 2$ contingency table $\left(\chi_{1}^{2}=402.4, P<0.001\right)$.

$\dagger$ Significantly different from WF, when tested using the

$2 \times 2$ contingency table $\left(\chi_{1}^{2}=50.5, P<0.001\right)$.

\section{Southern hybridization analysis}

RFLP analysis was used to exclude the possibility that progeny of the cross $\mathrm{AH} \times \mathrm{H} 8$ could originate by open or self-pollination. The anonymous DNA probe no. 35 revealed a reproducible DNA fragment length difference between the Olomouc ecotype (the $\mathrm{AH}$ and wild types) and the inbred line from Utrecht (H8). The Southern blot analysis of the Utrecht inbred line with the no. 35 probe revealed four hybridizing restriction fragments $(4.7,4.0,3.8$ and $3.5 \mathrm{~kb})$. Two of them (3.8 and $3.5 \mathrm{~kb})$ were specific for this genotype and were not present in the Olomouc ecotype. As these fragments were also found in the hermaphrodite H8 (Fig. 3, last line on right) and not in the androhermaphrodite $\mathrm{AH}$ (Fig. 3 , first line on left), we could use this probe to confirm the hybrid origin of plants obtained from the $\mathrm{AH} \times \mathrm{H} 8$ cross. In all five progeny plants tested (randomly chosen from the population), we observed a hybridization pattern with all four characteristic bands, confirming the hybrid origin of progeny (Fig. 3, F1-F5 lines).

\section{Discussion}

The androhermaphrodite trait cannot be transmitted through the egg and is linked to the $Y$ chromosome

The fact that no androhermaphrodites were found in the $\mathrm{AH} \times \mathrm{WM}$ cross but were frequent in the reciprocal cross $(\mathrm{WF} \times \mathrm{AH})$ confirmed our previous results on the uniparental inheritance of androher-

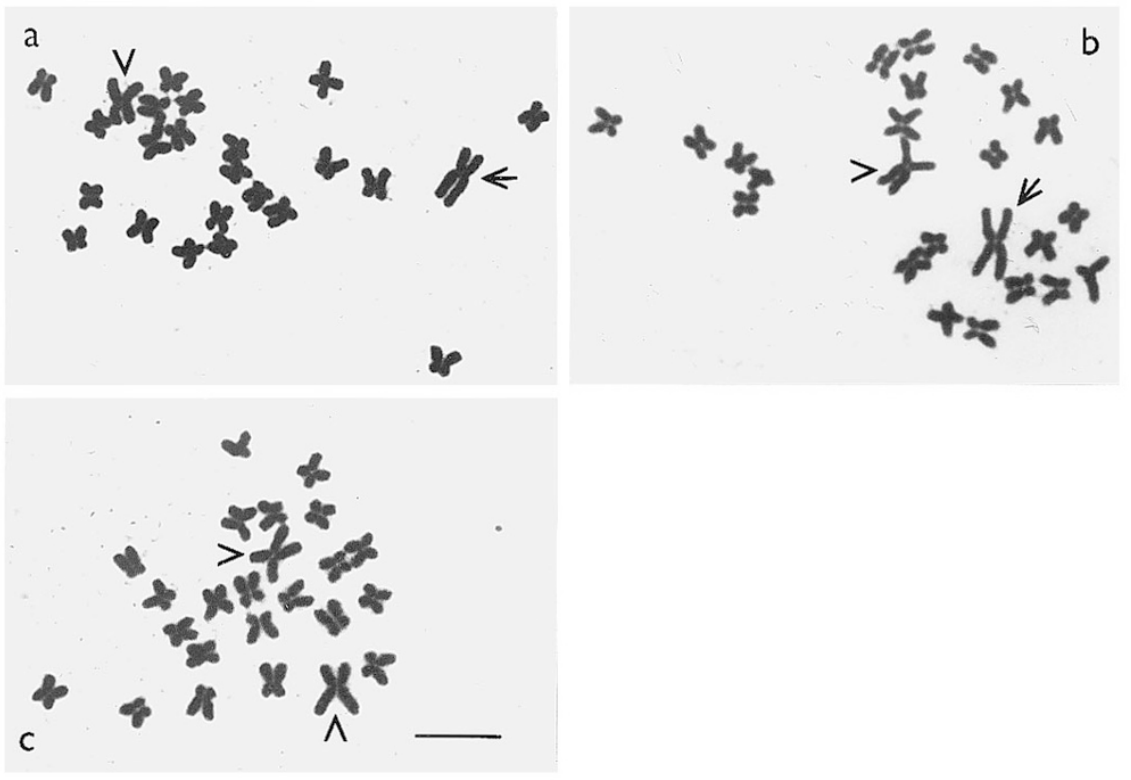

Fig. 2 Karyological analysis of Melandrium album plants. (a) Karyotype of the $\mathrm{H} 8$ hermaphrodite revealing a large deletion on one arm of the Y chromosome. (b) Standard male karyotype $(2 n=24, \mathrm{XY})$ of the androhermaphrodite $(\mathrm{AH})$ plant possessing the metacentric $\mathrm{Y}$ chromosome. (c) Representative metaphase from seedlings of the $\mathrm{AH} \times \mathrm{H} 8$ cross showing the female karyotype $(2 n=24, \mathrm{XX})$. The X and Y chromosomes are indicated by arrowheads and arrows respectively. Bar $=10 \mu \mathrm{m}$.

(c) The Genetical Society of Great Britain, Heredity, 80, 576-583. 
Table 2 Sexual phenotypes in progenies of crosses or self-pollinations among the wild-type female (WF), wild-type male (WM), androhermaphrodite (AH) and hermaphrodite (H8) Melandrium album

\begin{tabular}{|c|c|c|c|c|c|c|c|}
\hline & \multirow{2}{*}{$\begin{array}{c}\text { Seed } \\
\text { parent }\end{array}$} & \multirow{2}{*}{$\begin{array}{l}\text { Pollen } \\
\text { parent }\end{array}$} & \multicolumn{3}{|c|}{ Progeny (numbers of plants) } & \multirow[b]{2}{*}{ Females $(\%) \dagger$} & \multirow{2}{*}{$\begin{array}{c}\text { Androhermaphrodites } \\
\text { among XY } \\
\text { plants }(\%) \ddagger\end{array}$} \\
\hline & & & Females & Androhermaphrodites & Males & & \\
\hline (a) & WF & WM & 97 & 0 & 64 & $60^{*}$ & 0 \\
\hline (b) & $\begin{array}{l}\mathrm{H} 8 \\
\mathrm{H} 8 \\
\mathrm{WF}\end{array}$ & $\begin{array}{l}\mathrm{H} 8 \\
\mathrm{WM} \\
\mathrm{H} 8\end{array}$ & $\begin{array}{r}33 \\
6 \\
195\end{array}$ & $\begin{array}{l}0 \\
0 \\
0\end{array}$ & $\begin{array}{l}0 \\
4 \\
0\end{array}$ & $\begin{array}{c}100^{*} \\
60 \\
100^{*}\end{array}$ & $\begin{array}{c}- \\
-\end{array}$ \\
\hline (c) & $\begin{array}{l}\mathrm{AH} \\
\mathrm{AH} \\
\mathrm{WF}\end{array}$ & $\begin{array}{l}\mathrm{AH} \\
\mathrm{WM} \\
\mathrm{AH}\end{array}$ & $\begin{array}{l}36 \\
47 \\
26\end{array}$ & $\begin{array}{r}14 \\
0 \\
19\end{array}$ & $\begin{array}{r}6 \\
22 \\
4\end{array}$ & $\begin{array}{l}64^{* *} \\
68^{*} \\
53\end{array}$ & $\begin{array}{c}70 \\
0 \\
82 \S\end{array}$ \\
\hline (d) & $\begin{array}{c}\mathrm{AH} \\
\mathrm{H} 8\end{array}$ & $\begin{array}{l}\mathrm{H} 8 \\
\mathrm{AH}\end{array}$ & $\begin{array}{r}112 \\
15\end{array}$ & $\begin{array}{l}0 \\
4\end{array}$ & $\begin{array}{l}0 \\
3\end{array}$ & $\begin{array}{c}100^{*} \\
68\end{array}$ & $\overline{57}$ \\
\hline
\end{tabular}

$\dagger$ Frequency of females in the whole population of plants.

* Significant deviation from the expected one female to one male or androhermaphrodite ratio as tested by $\chi^{2}(P<0.01$ in all cases).

**Significant deviation from the expected one female to one male or androhermaphrodite ratio as tested by $\chi^{2}$ $(0.01<P<0.05)$.

$\$$ Number of androhermaphrodites/number of androhermaphrodites plus males.

$\S$ Significant deviation from the one male to one androhermaphrodite expected ratio for the autosomal inheritance of androhermaphroditism, as tested by $\chi^{2}(P<0.01)$.

maphroditism (Janoušek et al., 1996). The high abundance of androhermaphrodites in the $\mathrm{WF} \times \mathrm{AH}$ population ( $82 \%$ from the AAXY progeny plants) is unlikely to result from monogenic autosomal inheritance, as such a bias could only occur if an unusually strong selective advantage was conferred by the mutant allele. A more likely explanation is that the epimutation is $\mathrm{Y}$ chromosome linked and partially penetrant.

\section{AH F1 F2 F3 F4 F5 H8}

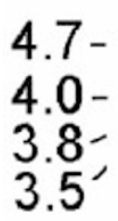

Fig. 3 Southern hybridization analysis of the genomic DNA samples prepared from parental Melandrium album (androhermaphrodite, $\mathrm{AH}$; and hermaphrodite, H8) and five female individuals from their progeny, $\mathrm{AH} \times \mathrm{H} 8(\mathrm{~F} 1-\mathrm{F} 5)$. All the samples were cleaved with $B g l I I$ and hybridized with the DNA probe no. 35 .
The $Y$ chromosome is not transmitted through the egg

The cross between the androhermaphrodite as the seed parent and the hermaphrodite $(\mathrm{AH} \times \mathrm{H} 8)$ showed that the $\mathrm{Y}$ chromosome cannot be transmitted through the female line, because neither males nor androhermaphrodites were found in the progeny. The progeny all had female karyotypes. The reciprocal cross $(\mathrm{H} 8 \times \mathrm{AH})$ excluded the possibility of a selective elimination of male and androhermaphrodite embryos as a consequence of intergenotype interactions. The new genetic background did not prevent the penetrance of the androhermaphroditism, because a high proportion of androhermaphrodites was present in this population.

Why is the $Y$ chromosome not transmitted through the egg?

There are a number of possible explanations to account for the inability of the Y chromosome to be transmitted through the female gametophyte. The complexity of potential problems is based on the fact that Melandrium forms the Polygonum type of embryo sac (Mól, 1993). Because of the monosporic origin of embryo sacs, all their cells must possess the same chromosome constitution, either AX or AY. The question is whether both these types of embryo sac are viable. 


\section{Can meiotic drive favour formation of $A X$ eggs?}

One of the possible mechanisms favouring $\mathrm{AX}$ megaspore formation could be meiotic drive, which can cause the preferential transfer of the X chromosome to the megaspore-forming pole during the first meiotic division (Lyttle, 1993). However, it has been demonstrated that the Y chromosome can be transmitted through the female line, because tetraploid hermaphrodites (4AXXYY), possessing an aberrant $\mathrm{Y}$ chromosome, were able to transmit the $\mathrm{Y}$ chromosome through female meiosis when crossed with wild-type males (Westergaard, 1946). In this case, megaspores of AAXY constitution were formed, i.e. the $\mathrm{X}$ chromosome was not absent. However, in our experiments, the $\mathrm{Y}$ chromosome non-transmissibility through the female line could be caused by the absence of an X chromosome in the initial AY megaspore or the resulting embryo sac.

\section{Are X-linked genes essential for egg development?}

Even though many researchers have tried for a long time to identify $\mathrm{X}$ chromosome-linked genes (Winge, 1931; Van Nigtevecht, 1966b) and to elucidate the possible role of the $\mathrm{X}$ chromosome in sex determination (Warmke, 1946), virtually nothing is known about this sex chromosome in M. album. Recent data indicate that, in female somatic cells of the AAXX chromosome constitution, one of the two $\mathrm{X}$ chromosomes is heavily methylated (Vyskot et al., 1993) and late-replicating (Široký et al., 1994), which suggests a similar $\mathrm{X}$ chromosome dosage phenomenon to Lyonization, described in mammals. The first attempt to clone $\mathrm{X}$ chromosome-derived DNA sequences yielded only subtelomeric repetitive clones also present on autosomes (Bužek et al., 1997). The presence of at least one $X$ chromosome is a prerequisite for plant sporophyte development (Ye et al., 1990; Veuskens et al., 1992), and only female somatic cells seem to be capable of plant regeneration in vitro ( $\mathrm{Wu}$ et al., 1993). The $\mathrm{X}$ chromosome must harbour some essential genes, because $M$. album cells, both somatic and generative, require the $X$ chromosome for survival with one exception: the short-lived male AY gametophyte, which seems, moreover, less viable (or effective) than the AX chromosome-harbouring gametophyte (Correns, 1928; Caroll \& Mulcahy, 1993; Taylor, 1994). In this case, some necessary nutritional and/or regulatory substances encoded by the $\mathrm{X}$ chromosome could be provided from the AAXY paternal anther tissues to form mature pollen grains and from the AAXX maternal pistil tissues to assist the development of pollen tubes. If so, this cross-feeding system apparently does not operate in the AY female gametophyte of the androhermaphrodite plant.

\section{Does incorrect sex chromosome ratio affect endosperm function?}

The role of endosperm in embryo development in the Caryophyllaceae family does not seem to be critical, as its nutritional function is partly substituted by the nucellus (Masand \& Kapil, 1966). This probably explains why $M$. album reciprocal crosses between tetraploid (4A4X or 4AXXYY, females or males respectively) and diploid plants (AAXY or AAXX, males or females respectively) were fertile and yielded both triploid females (3A3X) and triploid males (3AXXY) (Westergaard, 1940). It indicates that an unusual ratio of autosome sets in endosperm (four maternal sets to one paternal set or two maternal sets to two paternal sets of autosomes in reciprocal crosses) is tolerated in this plant in contrast to many other angiosperm species in which the correct autosome set ratio (two maternal sets to one paternal) is necessary for normal endosperm development because of imprinting (Haig \& Westoby, 1991). In our cross between the androhermaphrodite as the seed parent and the hermaphrodite as the pollen partner, two types of megaspores (AX and AY) and one type of microspores (only $\mathrm{AX}$, as the AY pollen is inviable because of the aberrant $\mathrm{Y}$ chromosome) could be expected. This would imply that the resulting female (AAXX) and male (AAXY) embryos would possess endosperm sex chromosome constitutions 3X:0Y and $1 \mathrm{X}: 2 \mathrm{Y}$ respectively. This sex chromosome ratio in endosperm is the same as in normal females (3X:0Y) but different from natural males $(2 \mathrm{X}: 1 \mathrm{Y})$. Therefore, the potential effect of a changed $\mathrm{X} / \mathrm{Y}$ chromosome ratio in the endosperm of $M$. album on the occurrence of males in the cross between the androhermaphrodite and the hermaphrodite cannot be excluded. Moreover, it is possible that the $\mathrm{X} / \mathrm{Y}$ chromosome ratio in endosperm cells also plays a role in the female bias, which is often explained (but without any direct evidence) as a result of pollen competition. It is worth mentioning that the different $\mathrm{X} / \mathrm{Y}$ ratio in the endosperm of female seeds (3X:0Y) and male seeds (2X:1Y) could represent a positive higher dosage effect of the $X$ chromosomes in female seeds or a negative effect of the $\mathrm{Y}$ chromosome in male seeds, and thus result in a higher viability of female embryos.

(C) The Genetical Society of Great Britain, Heredity, 80, 576-583. 


\section{Acknow ledgements}

We thank Ms Renáta Hladilová for excellent technical assistance. This work was supported by the Grant Agency of the Czech Academy of Sciences (A5004601).

\section{References}

BUŽEK, J., KOUTNÍKOVÁ, H., HOUBEN, A., ŘíHA, K., JANOUŠEK, B., ŠIROKÝ, J. ET $A L$. 1997. Isolation and characterisation of $\mathrm{X}$ chromosome-derived DNA sequences from a dioecious plant Melandrium album. Chrom. Res., 5, 57-65.

CAROLL, S. B. AND MULCAHY, D. L. 1991. The relationship between pollen grain size and progeny gender in dioecious Silene latifolia (Caryophyllaceae). Sex Plant Reprod., 4, 203-207.

CAROLl, S. B. AND MUlCAHY, D. L. 1993. Progeny sex ratios in dioecious Silene latifolia (Caryophyllaceae). Am. J. Bot., 80, 551-556.

CORRENS, C. 1928. Bestimmung, Vererbung und Verteilung des Geschlechtes bei den hoheren Pflanzen. Handbuch Vererbungswiss., 2, 1-138.

DEllaportA, S. L., WOOD, J. AND Hicks, J. B. 1983. A plant DNA minipreparation: version II. Plant Mol. Biol. Rep., 1, 19-21.

DONNISON, I. S., SIROKY, J., VYSKOT, B., SAEDLER, H. AND GRANT, S. 1996. Isolation of $\mathrm{Y}$ chromosome-specific sequences from Silene latifolia and mapping of male sex determining genes using representational difference analysis. Genetics, 144, 1891-1899.

GRANT, S., HOUBEN, A., VYSKOT, B., SIROKY, J., PAN, W.-H., MACAS, J. AND SAEDLER, H. 1994. Genetics of sex determination in flowering plants. Devel. Genet., 15, 214-230.

HAIG, D. AND WeStoby, M. 1991. Genomic imprinting in endosperm: its effect on seed development in crosses between species, and between different ploidies of the same species, and its implications for the evolution of apomixis. Phil. Trans. R. Soc. B, 333, 1-13.

JANOUŠEK, B., SIROKY, J. AND VYSKOT, B. 1996. Epigenetic control of sexual phenotype in a dioecious plant, Melandrium album. Mol. Gen. Genet., 250, 483-490.

LytTle, T. W. 1993. Cheaters sometimes prosper: distortion of Mendelian segregation by meiotic drive. Trends Genet., 9, 205-210.

MASAND, P. AND KAPIL, R. N. 1966. Nutrition of the embryo sac and embryo: a morphological approach. Phytomorphology, 16, 158-175.

MÓL, R. 1993. Embryo sac development during the culture of placenta attached ovules of Melandrium album. Biol. Plant., 35, 25-30.

ŠIROKÝ, J., JANOUŠEK, B., MOURAS, A. AND VYSKOT, B. 1994. Replication pattern of sex chromosomes in Melandrium album female cells. Hereditas, 120, 175-181.

TAYLOR, D. R. 1994. The genetic basis of sex ratio in Silene alba ( = S. latifolia). Genetics, 136, 641-651.

TAYLOR, D. R. 1993. Sex ratio in hybrids between Silene alba and Silene dioica. Evidence for Y-linked restorers. Heredity, 74, 518-526.

TESTOlin, R., CIPRIANI, G. AND COSTA, G. 1995. Sex segregation ratio and gender expression in the genus Actinidia. Sex. Plant Reprod., 8, 129-132.

VAN NIGTEVECHT, G. 1966a. Genetic studies in dioecious Melandrium. II. Sex determination in Melandrium album and Melandrium dioicum. Genetica, 37, 307-344.

VAN NIGTEVECHT, G. 1966b. Genetic studies in dioecious Melandrium. I. Sex-linked and sex-influenced inheritance in Melandrium album and Melandrium rubrum. Genetica, 37, 281-306.

VEUSKens, J., YE, D., OLIVEIRA, M., CIUPERCESCU, D. D., INSTALlÉ, P., VERHOVEN, H. A. ET AL. 1992. Sex determination in the dioecious Melandrium album: androgenic embryogenesis requires the presence of the $\mathrm{X}$ chromosome. Genome, 35, 8-16.

VYSKOT, B., ARAYA, A., VEUSKENS, J., NEGRUTIU, I. AND MOURAS, A. 1993. DNA methylation of sex chromosomes in a dioecious plant, Melandrium album. Mol. Gen. Genet., 239, 219-224.

WARMKE, H. E. 1946. Sex determination and sex balance in Melandrium. Am. J. Bot., 33, 648-660.

WestergaARD, M. 1940. Studies on cytology and sex determination in polyploid forms of Melandrium album. Dansk Botanisk Arkiv, 10, 1-131.

westergaArd, M. 1946. Aberrant Y chromosomes and sex expression in Melandrium album. Hereditas, 32, 419-443.

WESTERGAARD, M. 1958. The mechanism of sex determination in dioecious flowering plants. Adv. Genet., 9, 217-281.

WINGE, O. 1931. X- and Y-linked inheritance in Melandrium. Hereditas, 51, 127-165.

WU, Y., INSTALlÉ, P., HINNISDAELS, S., JACOBS, M. AND NEGRUTIU, I. 1993. Protoplast culture and female plant regeneration in the dioecious plant Melandrium album. Plant Cell Rep., 12, 211-215.

Ye, D., INSTAllé, P., CiUPeRCESCU, D., VeUSKens, J., WU, Y., SALESSES, G. ET AL. 1990. Sex determination in dioecious Melandrium I. First lessons from androgenic haploids. Sex. Plant Reprod., 3, 179-186. 